\title{
A Case of Pediatric Laryngeal Granular Cell Tumor
}

\author{
Jae Hwan Oh (D), Jun Suk Kim iD, Dong Young Kim (D), and Joo Hyun Woo (D) \\ Department of Otorhinolaryngology-Head and Neck Surgery, College of Medicine, Gachon University, Gil Medical Center, Incheon, Korea
}

소아의 후두에서 발생한 과립세포 종양 1 예

오재환, 김준석, 김동영, 우주현

가천대학교 의과대학 이비인후과학교실

Granular cell tumor is rare tumor origination from Schwann cell. It occurs extremely rarely in pediatric age. Treatment is complete resection, but this may not always be possible because of the risk of airway stenosis or vocal cord paralysis. Six year-old male patient visited otolaryngology clinic due to dyspnea and stridor. Posterior glottis mass was indentified and was partially resected to confirm histology and resolve airway obstruction. One year after operation, the patient was living well without re-growing of tumor. We report a case of granular cell tumor in pediatric larynx with a review of literature.

Keywords Granular cell tumor; larynx; pediatric.

\section{서 론}

과립 세포 종양(granular cell tumor)은 유병률 0.017 0.029\%의 드문 종양으로, 소아 에서 발생하는 경우는 극히 드물어 최근까지 10예가 보고되었다.1) 두경부에서 가장 흔 히 발생하며 후두 부위에 발생한 과립 세포 종양은 호흡곤란을 유발할 수 있다.2) 치료로 서는 종양의 수술적 완전 절제를 시행하는 것이 원칙이지만,3) 드문 증례로 인하여 치료 방법에 대한 완전한 합의는 없는 상태이다. 이에 저자들은 소아에서 발생한 후두에서 발 생한 과립세포종을 경험하였기에 문헌고찰과 함께 보고하고자 한다.

\section{증 례}

6세 남아가 발열, 기침, 천명음, 호흡곤란, 음성 변화를 주소로 본원 소아청소년과로 내원하였다. 과거 병력, 가족력 또는 출생시 특별한 증상력은 없었다. 소아과에서 크룹 진단 하 3주간의 보존적 치료 후, 발열, 기침 등의 증상은 호전되었으나, 천명음, 호흡곤 란, 음성 변화 등의 증상은 호전되지 않아 이비인후과로 의뢰되었다. 후두경 검사에서 성문후방에서 발생하여 성문 내경의 절반 정도를 막고 있는 가피양 표면의 점막 하 종 물이 관찰되었다(Fig. 1A). 경부 전산화단층촬영을 시행하였으며 이질성으로 조영 증 강되는 $9 \times 9 \times 21 \mathrm{~mm}$ 의 윤상 연골과 경계가 불명확한 종물이 관찰되었다(Fig. 1B).
Received May 19, 2020
Revised May 28, 2020
Accepted May 29, 2020

Corresponding Author Joo Hyun Woo, MD, PhD Department of OtorhinolaryngologyHead and Neck Surgery, College of Medicine,

Gachon University, Gil Medical Center, 21 Namdong-daero 774beon-gil, Namdong-gu, Incheon 21565, Korea Tel $+82-32-460-3765$

Fax+82-32-467-9044

E-mail woojh@gilhospital.com

\section{ORCID iDs}

Jae Hwan Oh (D)

https://orcid.org/0000-0002-1180-2581 Jun Suk Kim (D)

https://orcid.org/0000-0002-4203-0131 Dong Young Kim (D) https://orcid.org/0000-0001-5485-7198 Joo Hyun Woo (D) https://orcid.org/0000-0002-8584-563X

This is an Open Access article distributed under the terms of the Creative Commons Attribution Non-Commercial License (https://creativecommons.org/ licenses/by-nc/4.0) which permits unrestricted non-commercial use, distribution, and reproduction in any medium, provided the original work is properly cited. 


\section{JKSLP}

치료계획은 종물을 부분 절제하여 후두 폐쇄를 해결하고 동시에 조직학적 확진을 얻고자 하였다. 전신마취를 시행 후 성문 바로 상부에 현수후두경을 거치하였으며 이후 현수후두 경을 통해 $4.5 \mathrm{Fr}$ 삽관 튜브를 삽입하여 충분한 환기 이후 튜 브를 제거하고 산소포화도를 확인하면서 수술을 시행하였다 (Fig. 2A). 이러한 과정을 수 차례 반복하여 종물에 의한 후 두 폐쇄 부위를 절제할 수 있었다. 수술 이후 발생할 수 있는
성문후부 협착을 방지하기 위하여 정상점막을 보존하면서 쐐 기모양으로 종물을 절제하였다(Fig. 2B). 수술 1일 후 호흡곤 란과 천명음은 소실 되었으며, 성대 움직임은 양호한 상태로 퇴원하였다. 병리 검사 보고에서 다각형 모양의 핵과 함께 호 산구성 과립을 지닌 세포질의 모습을 보였으며(Fig. 3A), 면역 화학염색에서 S-100 Protein 양성으로 나타나(Fig. 3B) 과립 세포종으로 진단되었다.

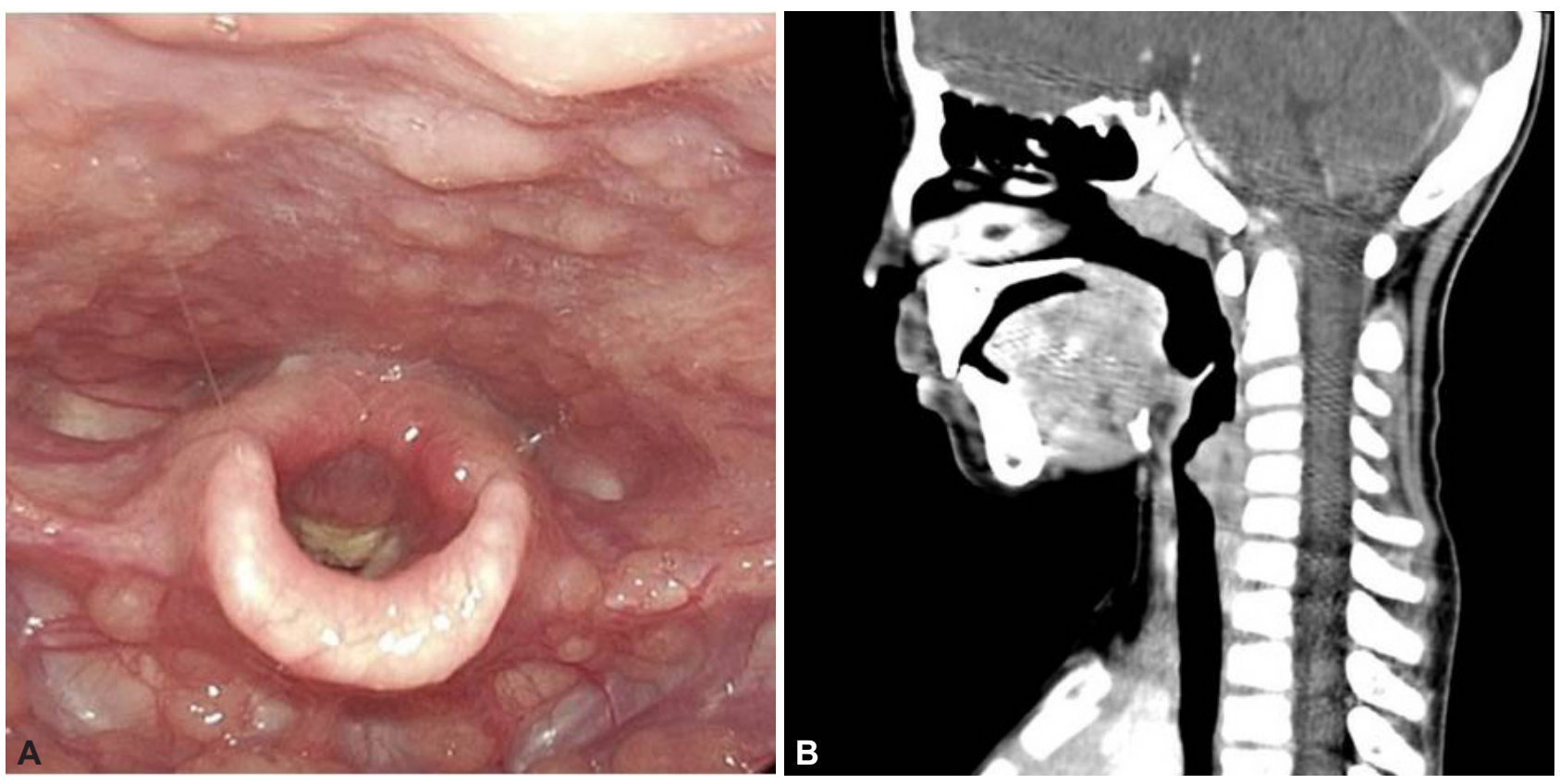

Fig. 1. Preoperative finding. Endoscopic view shows the whitish mass at the posterior glottis (A). Computed tomography showed about 1.5 $\mathrm{cm}$ length, hetergenously enhancing mass with ill-defined margin from the cricoid cartilage $(B)$.
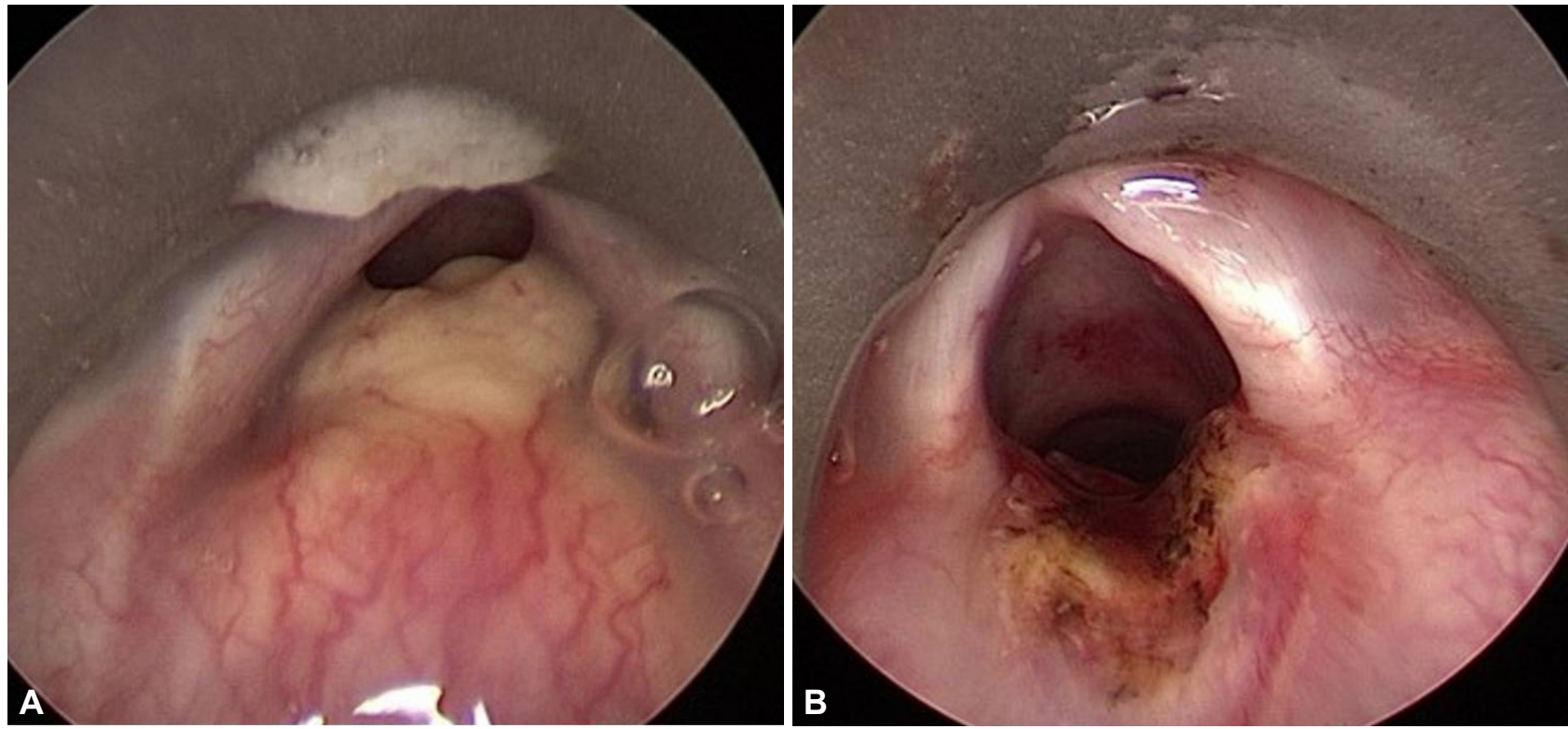

Fig. 2. Suspension laryngoscopic view. Submucosal mass with whitish necrotic surface was identified (A). The mass was partially resected with a wedge shape using $\mathrm{CO}_{2}$ laser $(\mathrm{B})$. 
술 후 12 개월 째 후두내시경 검사에서 재발소견 없으며(Fig. $4 \mathrm{~A})$, 경부 외측 단순 촬영에서 후두강 내로 돌출된 부분이 감 소된 상태로 기도가 유지되는 것이 관찰되었다(Fig. 4B). 환자 는 호흡곤란이나 다른 증상 없는 상태로 추적 관찰 중이다.

\section{고 찰}

이 증례는 소아 후두에서 발생한 과립세포 종양에 관한 보고이다. 과립 세포 종양은 양성 종양임에도 불구하고 국소 침윤이 발생한다. ${ }^{1)}$ 하지만 소아에서 악성화로 진행된 보고는
없다.1,4) 인후두에서 발생한 과립 세포 종양은 목소리 변화, 삼킴 곤란, 이물감을 유발한다. ${ }^{5}$ 양성종양의 특성상 점진적 으로 자라기 때문에 국소 조직 파괴 혹은 기도 폐쇄에 의한 증상이 발생하기 전까지 진단이 늦춰질 수 있다.2)

추천되는 치료는 수술에 의한 완전 절제이며 완전 절제가 시행된 경우 재발율은 2 3\%에 국한되는 것으로 알려져 있 다. ${ }^{3)}$ 완전 절제가 이루어지지 않았을 경우 재발율은 8 21\% 로 재발 가능성이 높아진다.2,6) Daniel 등ㄱ은 종물의 크기가 $1 \mathrm{~cm}$ 보다 큰 경우 기관 벽을 따라 기관 벽 전층이 포함될 수 있어 기관내 절제로는 종물의 완전 절제가 어렵다고 보고하
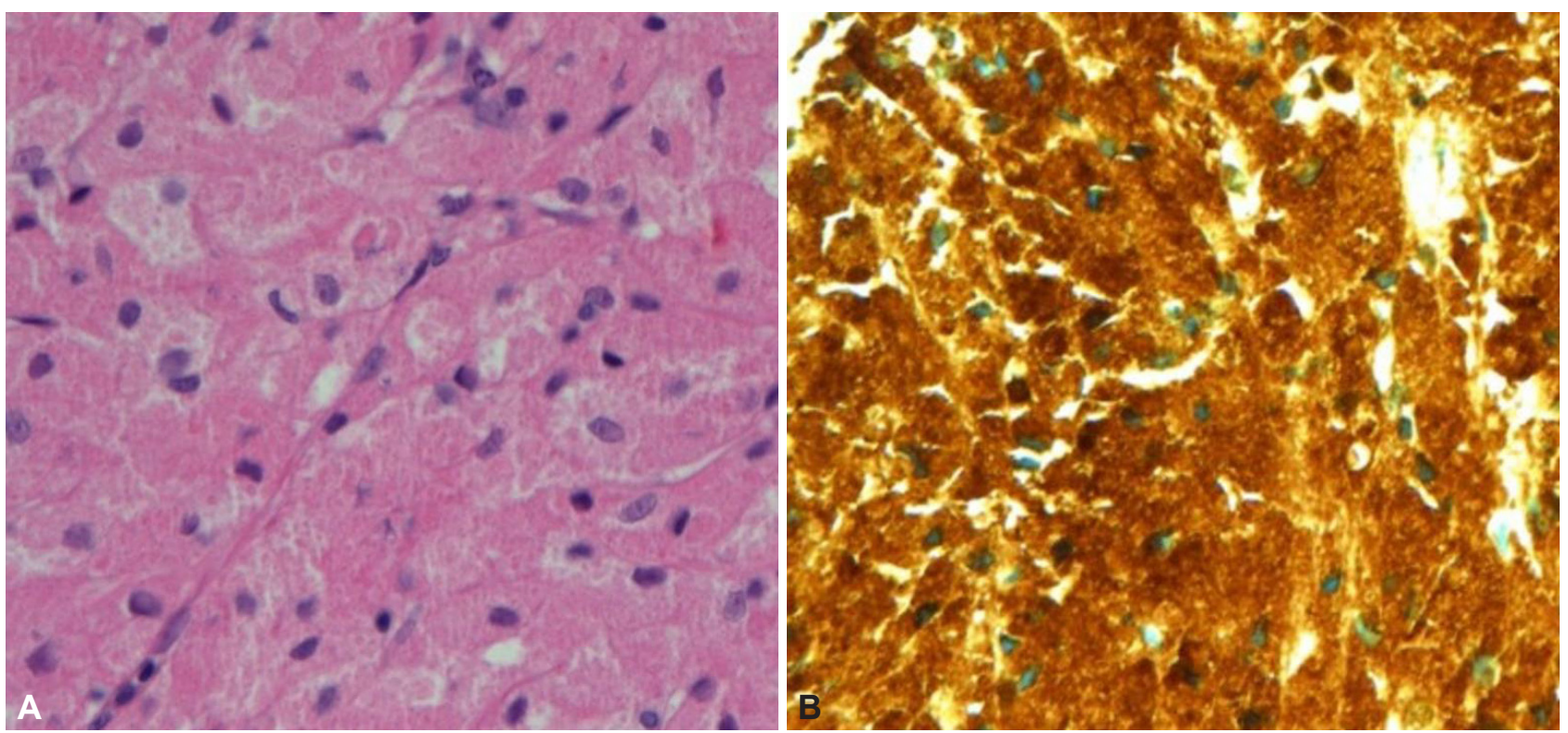

Fig. 3. Pathologic report. Eosinophilic granules in cytoplasm and polygonal nucleus in the cell were found (H\&E stain. $\times 400)(A) . S-100$ protein was positive in immucohistochemistry $(\times 400)(B)$.
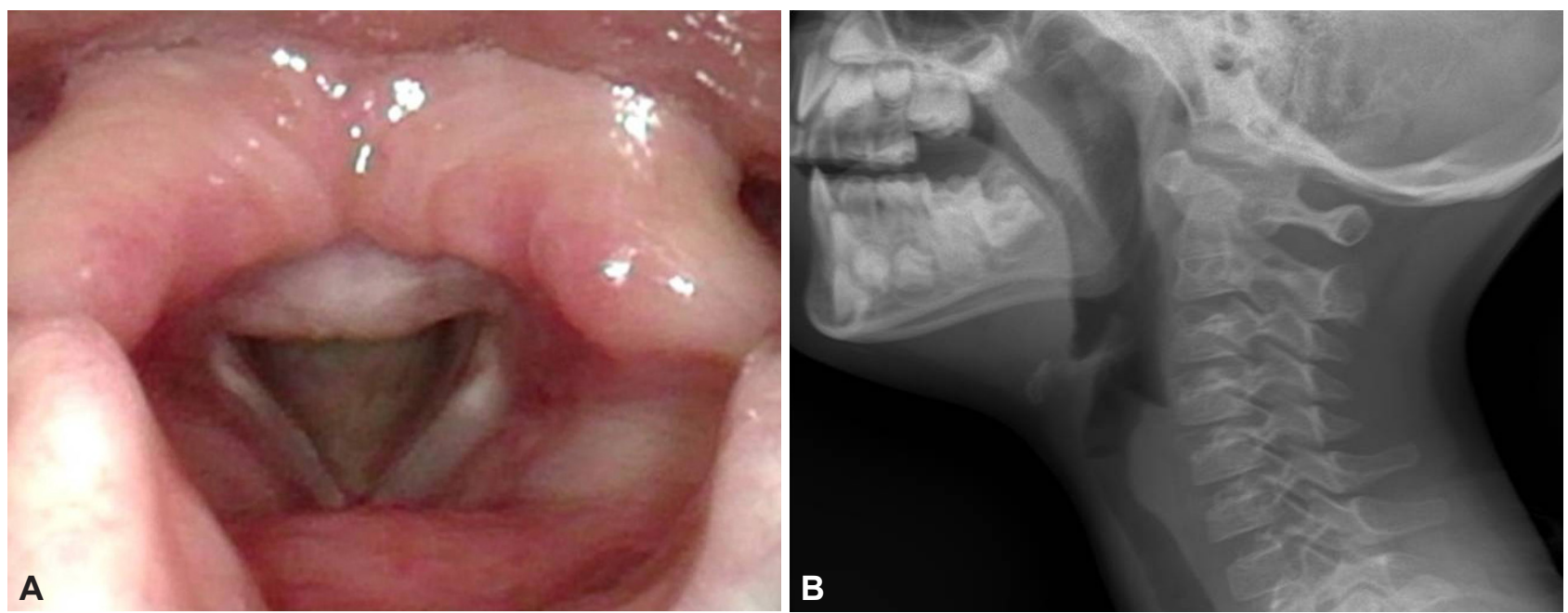

Fig. 4. Postoperative 1 year following up finding. Laryngoscope did not show re-growing of tumor (A). Lateral neck X-ray shows a little widening of airway at glottis level (B). 
였다.) 방사선에 대한 감수성이 없고 악성 형질 변환을 야기 할 가능성이 있어 방사선 치료는 추천되지 않는다. ${ }^{8}$

본 환자의 경우 $1 \mathrm{~cm}$ 이상의 크기를 지닌 후두와 기관에 걸친 과립 세포 종양이 확인되었다. 유사한 증례에 대한 기 존의 증례보고에서는 후두와 기관절개를 통해 점막하 종양 의 완전절제를 시행하였다. ${ }^{2)}$ 하지만 본 증례의 경우 이미 점 막 손상이 와 있는 상태이며 윤상연골과의 박리가 어려울 것 으로 판단되었다. 완전절제를 계획한다면 과도한 점막손상과 윤상연골 후벽의 손상으로 인한 기도협착이 발생할 위험성 이 예상되었다. 그래서 증상의 경감과 조직학적 확진을 위해 부분절제를 계획하였다. 정상점막은 보존하고 괴사된 점막 을 포함한 쇄기형태의 절제가 시행되었으며 환자는 수술 이 후 호흡곤란 없어졌고 1 년의 추적관찰 결과 종물 크기 증가 는 없었다. 저자들은 본 증례를 통해 소아의 후두에서 발생 한 과립세포종양을 치료할 때 기존의 보고들과 달리 침습적 인 수술보다는 보존적인 부분절제를 통해서도 호흡곤란과 같은 증상을 해결하고 정상적인 생활이 가능할 수 있다는 것 을 알 수 있었다. 제한 된 증례로 인해 종물의 재발 또는 크 기 증가의 시기 등에 대한 예측하기는 어렵지만 장기간 추적 관찰을 통해 재발여부를 확인할 예정이다.

중심 단어: 과립 세포 종양, 후두, 소아.

Acknowledgments

None.
Conflicts of Interest

The authors have no financial conflicts of interest.

Authors' Contribution

Conceptgualization: Joo Hyun Woo, Dong Young Kim. Data curation: Joo Hyun Woo, Jae Hwan Oh, Jun Suk Kim. Investigation: Joo Hyun Woo, Jae Hwan Oh. Methodology: Joo Hyun Woo, Dong Young Kim. Resources: Joo Hyun Woo. Visualization: Joo Hyun Woo, Jae Hwan Oh, Jun Suk Kim. Writing-original draft: Joo Hyun Woo, Jae Hwan Oh. Writing-review \& editing: Joo Hyun Woo, Jae Hwan Oh. Approval of final manuscript: all authors.

\section{REFERENCES}

1. Gonik NJ, Zeltsman D, Smith LP. Complicated pediatric subglottic granular cell tumor with extensive intraluminal and extraluminal invasion. Int J Pediatr Otorhinolaryngol 2014;78(9):1563-5.

2. Torre M, Yankovic F, Herrera O, Borel C, Latorre JJ, Aguilar P, Varela P, et al. Granular cell tumor mimicking a subglottic hemangioma. J Pediatr Surg 2010;45(12):e9-11.

3. Compagno J, Hyams VJ, Ste-Marie P. Benign granular cell tumors of the larynx: a review of 36 cases with clinicopathologic data. Ann Otol Rhinol Laryngol 1975;84(3 Pt 1):308-14.

4. Sobol SE, Samadi DS, Wetmore RF. Pediatric subglottic granular cell myoblastoma. Otolaryngol Head Neck Surg 2005;132(4):655-7.

5. Robb PJ, Girling A. Granular cell myoblastoma of the supraglottis. J Laryngol Otol 1989;103(3):328-30.

6. Fanburg-Smith JC, Meis-Kindblom JM, Fante R, Kindblom LG. Malignant granular cell tumor of soft tissue: diagnostic criteria and clinicopathologic correlation. Am J Surg Pathol 1998;22(7):779-94.

7. Daniel TM, Smith RH, Faunce HF, Sylvest VM. Transbronchoscopic versus surgical resection of tracheobronchial granular cell myoblastomas. Suggested approach based on follow-up of all treated cases. J Thorac Cardiovasc Surg 1980;80(6):898-903.

8. Yoo YS. A case of granular cell tumor in the larynx. Korean J Otorhinolaryngol-Head Neck Surg 1994;37(4):833-7. 